LETTER TO THE EDITOR

\title{
Surgical treatment of malignant pleural effusions
}

\author{
Kovacicova K \\ Department of Surgery, The Merciful Brothers Hospital in Brno Czech Republic
}

In 2010, P. Habal (Habal P. et al. Monitoring the effectiveness of surgical treatment of malignant pleural effusions. Klin Okol 2010;23:(2):99-103) reported their results in the treatment of recurrent malignant pleural effusions by video-assisted thoracoscopic surgery (VATS) using talc for chemical pleurodesis. They concluded that the success of pleurodesis is influenced by the overall body inflammatory response. Based on current researchs and our observation we can confirm his finding regarding the relationship between the intensity of the induced inflmmation and the outcome of pleurodesis. The role of the surgical stress must be considered as it can trigger systemic inflammatory response. Another factor that determine the outcome of pleurodesis is the adequete contact between the visceral and parietal pleural (Habal P. et al. The dynamics of selected local inflammatory markers to talc in the treatment of malignant pleural effusions. Biomed Pap Med Fac Univ Palacky Olomouc Czech Repub. 2013Dec;157(4):311$315)$. Another report presented the significant impact of changes in proinflammatory and anti-inflammatory cellular and soluble receptors reflecting the acitivity of the ongoing inflammatory reaction in the pleural cavity (Jankovicova K. et al. TLR2 in pleural fluid is modulated by talc pleurodesis During particles . Clinical and Developmental Immunology Volume 2012; Article ID 1582 87 ,doi:10.1155/2012/158287). One of the adverse side effects of such an induced systemic inflammatory response is coagulation disorder, which is expected especially in patients with impaired hepatic function after chemotherapy. The risk factors associated with blood derivatives administration is highlighted in the journal The Heart Surgery Forum (Omran N. et al. Recombinant Activated Factor VII Administration after Pulmonary embolectomy: Case Report. The Heart Surgery Forum, 2013;1026.16 (4):1-3). Although VATS has been introduced into the clinical practise in the the early $20^{\text {th }}$ century, the incresing knowledge about its application made it a reliable diagnostic and therapeutic method for an increasing number of patients.

\section{References}

1. P. Habal, J. Mand'ák, J. Šimek, M. Štětina, K. Jankovičová, K. Kondělková, J. Krejsek Monitorace efektivity chirurgické léčby maligních pleurálních výpotků. Klin Okol 2010;23(2):99-103.

2. Habal P, Jankovicova K, Omran N, Kondelkova K, Krejsek J, Mandak $\mathbf{J}$. The dynamics of selected local inflammatory markers to talc in the treatment of malignant pleural effusions. Biomed Pap Med Fac Univ Palacky Olomouc Czech Repub. 2013 Dec;157(4):311-315.

3. Jankovicova K, Kondelkova K, Habal P, Andrys C, Krejsek J, Mandak J. TLR2 in pleural fluid is modulated by talc particles during pleurodesis. Clinical and Developmental Immunology Volume 2012; Article ID 158287,7 pages doi:10.1155/2012/158287.

4. Omran N, Harrer J, Brtko M, Habal P, Turek Z, Brozik J. Recombinant Activated Factor VII Administration after Pulmonary Embolectomy: Case Report. The Heart Surgery Forum, 2013;1026,16(4):1-3.

Received January 8, 2014. 